\title{
NOACs: an emerging class of oral anticoagulants-a review article
}

\author{
Chithra Paul $^{1 *}$ (D), Mable Baby ${ }^{1}$, Alfet Raju Anthraper ${ }^{1}$ and Krishnakumar K²
}

\begin{abstract}
Background: NOACs, commonly known as novel oral anticoagulants, are the non-vitamin $\mathrm{K}$ antagonist oral anticoagulants which are relatively newer in the market. It has displaced vitamin $\mathrm{K}$ antagonists, notably warfarin, for many indications. These agents are dabigatran, rivaroxaban, apixaban, and edoxaban.

Main body: The drugs are licenced to prevent stroke and also systemic embolism in patients on treatment for atrial fibrillation and prevent venous thromboembolism. Rivaroxaban and apixaban are approved for prophylaxis of thrombus following surgical hip or knee arthroplasty. The recent surveys reveal that use of NOACs has steeply increased due to its safety profile and convenience to use. Also, the studies have shown that NOACs have lesser bleeding complications and associated mortality in contrast to traditional anticoagulants. The upcoming years are known to be NOACs' age due to the significant findings in this area.

Conclusion: Therefore, a basic understanding on these drugs is highly recommended to provide a better service to the patients. This article aims to provide quick and brief information on the novel class of drugs. It equips an overview of NOAC and deals with the following areas: (i) pharmacology, (ii) laboratory methods, (iii) peri-operative management, (iv) advantages, (v) challenges, and (vi) future.
\end{abstract}

Keywords: NOAC, VKA, Anticoagulants

\section{Background}

Oral anticoagulants are drugs that are extensively used for the extended prevention and therapy of thromboembolism in veins and arteries [1]. Initially, vitamin $\mathrm{K}$ antagonists were the only feasible oral anticoagulants [2]. There is a substantial downside with the use of vitamin $\mathrm{K}$ antagonists (VKAs) such as increased risk of bleeding, narrow therapeutic index, individualized dosing based on INR, and many more $[2,3]$. Novel oral anticoagulants (NOACs) resolved these issues to a remarkable extent. It is at least as effective as traditional anticoagulants and is convenient to administer as it is given as fixed doses without routine coagulation monitoring [1]. It has a predictable and consistent PK-PD

\footnotetext{
* Correspondence: chithrapaul11@gmail.com

'Department of Pharmacy Practice, St. James' College of Pharmaceutical Sciences, St. James' Hospital Trust Pharmaceutical Research Centre (DSIR recognized), Chalakudy, Kerala, India

Full list of author information is available at the end of the article
}

profile [4]. NOACs include four drugs, of which, dabigatran was the first to be FDA approved in 2010. It is a direct thrombin inhibitor. Rivaroxaban, apixaban, and edoxaban fall under direct factor Xa inhibitors that were approved on 2011, 2014, and 2015, respectively [5].

\section{Main text}

Pharmacological aspects of NOACs

Unlike VKAs, NOACs have more predictable PK-PD properties [4]. Due to this appreciable characteristic, NOACs are used at fixed doses without periodic monitoring of coagulation parameters [6]. A relevant relationship allying clinical characteristics and plasma drug levels and/or pharmacodynamics responses with safety and efficacy has been established by pharmacokineticspharmacodynamics analyses of vital trials with NOACs. Absolving these analyses, dosing instructions and contraindications are placed on the basis of clinical characteristics in relation to plasma drug levels and/or 
pharmacodynamics responses, reduction of stroke, and bleeding chances are provided by pharmaceutical manufacturers and regulatory authority to make effective use of the risk and benefit profile of NOACs in the current world. By knowing the effect of these factors on blood levels, it is certain that for almost all patients, the drug exposure falls within a limit without monitoring coagulation (Tables 1 and 2) [8].

\section{Mechanism of action}

NOACs act by two different mechanisms. Based on this, it is grouped as direct thrombin inhibitor and direct factor $\mathrm{Xa}$ inhibitor. The former category inhibits coagulation by directly binding to thrombin and prevents the formation of fibrin by restricting thrombin from breaking fibrinogen. The latter group inhibits factor Xa which is trypsin-like serine protease that plays a critical role in the blood coagulation cascade [9]. It has a principal position in linking the intrinsic and extrinsic pathways to the final common coagulation pathway. These agents bind directly to factor $\mathrm{Xa}$ and prevent them from cleaving prothrombin to thrombin [10].

\section{Laboratory tests}

Due to the predictable characteristics of NOACs, routine monitoring to assess the coagulation is not necessary. However, testing may be useful in specific situations such as patients who are bleeding, are overdosed, or require invasive procedures [11]. The available tests can be divided based on the process of measurement.

\section{Clot-based assays}

Assays based on clot formation are widely available. These tests work by measuring the time period for the plasma-containing NOAC to be monitored to form coagulum after adding calcium and activator. It includes prothrombin time $(\mathrm{PT})$, dilute prothrombin time, activated partial thromboplastin time (aPTT), hep test, ecarin clotting time (ECT), and hemoclot as well as prothrombinase-induced clotting time (PiCT). However, these are not specific to NOACs [12].

PT is used to assess the coagulation with rivaroxaban. It determines the time taken as the plasma sample produces clot after adding calcium along with thromboplastin. The final results are generated as seconds. The limitations for the test are high inter-laboratory variability; patients with hepatic impairment or sepsis may show protracted PT results, as well as transient PT values may be obtained due to the short half-life of the drug. Also, PT reagents are insensitive at a low concentration of the drug producing false results. Dilute PT assays also show the same limitations. Neoplastine plus is the suggested agent to estimate the effect of the drug [13-15].
aPTT test is used to monitor coagulation of rivaroxaban and apixaban. It estimates comprehensive functioning of the intrinsic coagulation pathway. It is executed by adding contact activator and cephalins to a plasma sample that has been citrated. The preincubation period is provided before the addition of calcium, and then the measurement of clotting time is performed [12]. However, it is less sensitive than PT. It can be used as a screening test [16].

HepTest is an anti-factor Xa analysis based on clot formation. Calcium chloride and thromboplastin are added to plasma sample after incubation with bovine factor Xa. This test is used to estimate the coagulation with rivaroxaban [14]. ECT is another test to determine the clotting of thrombin using venom obtained from snake to form prothrombin intermediate. Even though it has been found to be useful for monitoring dabigatran activity, it lacks sensitivity and does not have an available system for standardization and validation [17]. Whereas hemoclot is a test used to determine dabigatran that is found to have high sensitivity and good reproducibility $[13,16], \mathrm{PiCT}$ is a reliable method for assessing rivaroxaban and dabigatran in blood samples. Like all the tests, it lacks sensitivity at low concentrations [12].

\section{Chromogenic assays}

Chromogenic assays are quantitative tests that determine the variation in absorbance using chromophore labelled substrate. The coagulation factor to be determined cleaves the labelled substrate of a particular clotting factor, which is a process blocked by the anticoagulant. These assays are more certain than clot-based assays. It is a very useful technique to measure the coagulation of rivaroxaban and provide accurate results [12].

Recently, STA Rotachrom, Technochrom ${ }^{\odot}$ anti-Xa, and Biophen $\mathrm{DiXaI}^{\oplus}$ have received European sanction for trade purposes. STA Rotachrom is anti-factor $\mathrm{Xa}$ chromogenic test which helps in assessing the activity of both rivaroxaban and apixaban. It is more precise and a definite substitute to the prothrombin test for estimating rivaroxaban $[18,19]$.

\section{Liquid chromatography-mass spectrometry(LC-MS/MS)}

Liquid chromatography-coupled tandem mass spectroscopy is the novel type of measurement of anticoagulants and is helpful in clinical situations where the bleeding cause is yet to be determined. It is the most reliable laboratory assay to investigate the plasma level of the drugs. It is highly specific and provides reliable and accurate results. The simultaneous determination of dabigatran, rivaroxaban, and apixaban can be done within 3 min. The main limitation of the assay is that it is only available in specialized laboratories. Thus, it can be used as an arbitration method for serious conditions [20]. 
Table 1 Clinical profile of NOACs [7]

\begin{tabular}{|c|c|c|c|c|}
\hline Anticoagulant & Dabigatran & Rivaroxaban & Apixaban & Edoxaban \\
\hline $\begin{array}{l}\text { Mechanism of } \\
\text { action }\end{array}$ & Direct thrombin inhibitor & Direct factor Xa inhibitor & Direct factor Xa inhibitor & Direct factor Xa inhibitor \\
\hline Prodrug & Yes & No & No & No \\
\hline Absorption & Rapid & Rapid & $3-4 \mathrm{~h}$ & Rapid \\
\hline Bioavailability & $6 \%$ & $\begin{array}{l}66 \% \text { w/o food Up to } 100 \% \\
\text { with food }\end{array}$ & $50 \%$ & $62 \%$ \\
\hline Half-life & $12-17 \mathrm{~h}$ & $\begin{array}{l}\text { 5-9 h(young) 11-13 } \\
\text { h(elderly) }\end{array}$ & $12 \mathrm{~h}$ & $9-11 \mathrm{~h}$ \\
\hline Vd & $50-70 \mathrm{~L}$ & $50 \mathrm{~L}$ & $21 \mathrm{~L}$ & $107 \mathrm{~L}$ \\
\hline $\begin{array}{l}\text { Time to reach } \\
\text { max. plasma } \\
\text { conc. }\end{array}$ & $0.5-2 \mathrm{~h}$ & $2-4 h$ & $1-4 h$ & $1-2 h$ \\
\hline $\begin{array}{l}\text { Protein } \\
\text { binding }\end{array}$ & $35 \%$ & $92-95 \%$ & $87 \%$ & $55 \%$ \\
\hline $\begin{array}{l}\text { Liver } \\
\text { metabolism }\end{array}$ & No & Yes & Yes & Minimal \\
\hline $\begin{array}{l}\text { Renal } \\
\text { excretion }\end{array}$ & $80 \%$ & $35 \%$ & $25 \%$ & $50 \%$ \\
\hline $\begin{array}{l}\text { Gastro- } \\
\text { intestinal } \\
\text { tolerability }\end{array}$ & Dyspepsia & No Problem & No Problem & No Problem \\
\hline $\begin{array}{l}\text { Absorption } \\
\text { with food }\end{array}$ & No effect & $39 \%$ \& above & No effect & $6-22 \%$ more \\
\hline Effect of diet & $\begin{array}{l}\text { Delays absorption; time to } \\
\text { reach peak level extends to } \\
4 \mathrm{~h}\end{array}$ & $\begin{array}{l}\text { Peak levels attain at } 3 \mathrm{~h} \text { on } \\
\text { fasting and } 4 \mathrm{~h} \text { with food. } \\
\text { Factor Xa inhibition higher } \\
\text { with food }\end{array}$ & No effect on exposure & No effect on exposure \\
\hline Effect of age & $\begin{array}{l}\text { Bioavailability is } 1.7-2 \text { times } \\
\text { high in elders }\end{array}$ & $\begin{array}{l}\text { Bioavailability is greater in } \\
\text { elderly with half-life } 11-13 \\
\mathrm{~h} \text { with no difference in } \\
\text { concentration }\end{array}$ & $\begin{array}{l}\text { Exposure is } 32 \% \text { greater in patients } \\
\text { above } 65 \text { years of age }\end{array}$ & $\begin{array}{l}\text { Exposure is } 32 \% \text { greater in patients } \\
\text { over } 65 \text { years of age }\end{array}$ \\
\hline $\begin{array}{l}\text { Effect of } \\
\text { body weight }\end{array}$ & None & $\begin{array}{l}\text { Weight }<50 \mathrm{~kg} \text { have } 24 \% \\
\text { increased exposure \& } \\
\text { weight }>120 \mathrm{~kg} \text { have } 24 \% \\
\text { reduced exposure }\end{array}$ & $\begin{array}{l}\text { Weight }<50 \mathrm{~kg} \text { have } 20-30 \% \text { in- } \\
\text { creased exposure \& weight }>120 \\
\text { kg have } 20-30 \% \text { reduced exposure }\end{array}$ & $\begin{array}{l}\text { Weight }<50 \mathrm{~kg} \text { have } 20-30 \% \text { in- } \\
\text { creased exposure \& weight }>120 \\
\text { kg have } 20-30 \% \text { reduced exposure }\end{array}$ \\
\hline $\begin{array}{l}\text { Effect of renal } \\
\text { impairment }\end{array}$ & $\begin{array}{l}\text { Severely impaired; } 6 \text { times } \\
\text { higher exposure with half- } \\
\text { life } 28 \mathrm{~h}\end{array}$ & $\begin{array}{l}\text { Similar increase in } \\
\text { exposure with moderate } \\
\text { or severe renal impairment }\end{array}$ & $\begin{array}{l}\text { No effect on peak concentration. } \\
\text { Increase in exposure of } 16,29 \text {, and } \\
44 \% \text { for creatinine clearance of } 51- \\
80,30-50 \text {, and } 15-29 \% \mathrm{ml} / \mathrm{min} \text {, } \\
\text { respectively. }\end{array}$ & $\begin{array}{l}\text { No effect on peak concentration. } \\
\text { Increase in exposure of } 16,29 \text {, and } \\
44 \% \text { for creatinine clearance of } 51- \\
80,30-50 \text {, and } 15-29 \% \mathrm{ml} / \mathrm{min} \text {, } \\
\text { respectively. }\end{array}$ \\
\hline $\begin{array}{l}\text { Effect of } \\
\text { hepatic } \\
\text { impairment }\end{array}$ & $\begin{array}{l}\text { None with Child-Pugh classi- } \\
\text { fication B }\end{array}$ & $\begin{array}{l}\text { Significantly increased on } \\
\text { exposure with Child-Pugh } \\
\text { classification B }\end{array}$ & $\begin{array}{l}\text { No change in exposure with Child- } \\
\text { Pugh classification A or B }\end{array}$ & $\begin{array}{l}\text { No change in exposure with Child- } \\
\text { Pugh classification A or B }\end{array}$ \\
\hline Doses & 75 mg, $110 \mathrm{mg}, 150 \mathrm{mg}$ & $\begin{array}{l}2.5 \mathrm{mg}, 10 \mathrm{mg}, 15 \mathrm{mg}, 20 \\
\mathrm{mg}\end{array}$ & $2.5 \mathrm{mg}, 5 \mathrm{mg}$ & $15 \mathrm{mg}, 30 \mathrm{mg}, 60 \mathrm{mg}$ \\
\hline Dosing & Two times a day & One time a day & Two times a day & One time a day \\
\hline Dosage form & Capsule & Tablet & Tablet & Tablet \\
\hline ADR & $\begin{array}{l}>10 \% \text { gastro-intestinal } \\
\text { symptoms (like dyspepsia); } \\
1-10 \% \text { gastritis, esophagitis; } \\
<1 \% \text { allergic oedema, } \\
\text { thrombocytopenia }\end{array}$ & $\begin{array}{l}>10 \% \text { haematologic and } \\
\text { oncologic haemorrhage; } \\
1-10 \% \text { pruritus, abdominal } \\
\text { pain; }<1 \% \text { angioedema, } \\
\text { cholestasis }\end{array}$ & $\begin{array}{l}>10 \% \text { haematologic and oncologic } \\
\text { haemorrhage; } 1-10 \% \text { haematuria, } \\
\text { epistaxis; }<1 \% \text { hyper-sensitivity re- } \\
\text { action, haematoma }\end{array}$ & $\begin{array}{l}>10 \% \text { haematologic and oncologic } \\
\text { haemorrhage; } 1-10 \% \text { skin rash, } \\
\text { anaemia; }<1 \% \text { intra cranial } \\
\text { haemorrhage, interstitial pulmonary } \\
\text { disease }\end{array}$ \\
\hline $\begin{array}{l}\text { Contra } \\
\text { indications }\end{array}$ & $\begin{array}{l}\text { Serious hyper-sensitivity } \\
\text { reactions }\end{array}$ & $\begin{array}{l}\text { Serious hyper-sensitivity } \\
\text { reactions }\end{array}$ & Serious hyper-sensitivity reactions & Serious hyper-sensitivity reactions \\
\hline
\end{tabular}


Table 2 NOACs - indications and doses [7]

\begin{tabular}{|c|c|c|c|c|}
\hline Drug & $\begin{array}{l}\text { Non-valvular atrial } \\
\text { fibrillation (to } \\
\text { prevent stroke and } \\
\text { systemic embolism) }\end{array}$ & $\begin{array}{l}\text { Venous thromboembolism } \\
\text { prophylaxis }\end{array}$ & DVT and PE & Others \\
\hline Dabigatran & 150 mg twice daily & $\begin{array}{l}110 \mathrm{mg} 1 \text { to } 4 \mathrm{~h} \text { after completion of } \\
\text { surgery and establishment of } \\
\text { haemostasis, or the initial dose of } 220 \\
\text { mg after haemostasis is achieved and } \\
\text { continued for } 10-14 \text { days }\end{array}$ & 150 mg twice daily & \\
\hline Rivaroxaban & $\begin{array}{l}20 \text { mg once daily with } \\
\text { the evening meal }\end{array}$ & $10 \mathrm{mg}$ once daily for 31-39 days & $\begin{array}{l}15 \mathrm{mg} \text { twice daily with } \\
\text { food for } 21 \text { days } \\
\text { followed by } 20 \mathrm{mg} \\
\text { once daily with food }\end{array}$ & $\begin{array}{l}\text { CAD: } 2.5 \mathrm{mg} \text { twice daily with low-dose as- } \\
\text { pirin; heparin-induced thrombocytopenia: } \\
15 \mathrm{mg} \text { daily with food for } 21 \text { days followed } \\
\text { by } 20 \mathrm{mg} \text { once daily }\end{array}$ \\
\hline Apixaban & $5 \mathrm{mg}$ twice daily & $\begin{array}{l}2.5 \mathrm{mg} \text { twice daily beginning } 12-24 \mathrm{~h} \\
\text { post-operatively }\end{array}$ & $\begin{array}{l}10 \text { mg twice daily for } \\
7 \text { days followed by } 5 \\
\text { mg twice daily }\end{array}$ & $\begin{array}{l}\text { Heparin-induced thrombocytopenia: } 10 \mathrm{mg} \\
\text { twice daily for } 7 \text { days followed by } 5 \mathrm{mg} \\
\text { twice daily }\end{array}$ \\
\hline Edoxaban & 60 mg once daily & & $\begin{array}{l}\text { Patient weight }>60 \mathrm{~kg} \text {, } \\
60 \mathrm{mg} \text { once daily, and } \\
\leq 60 \mathrm{~kg}, 30 \mathrm{mg} \text { once } \\
\text { daily }\end{array}$ & \\
\hline
\end{tabular}

\section{Peri-operative management of NOAC}

The faster onset and offset of action of NOACs have made the peri-operative management fairly easy. NOACs should be pre-operatively paused for operation with a high chance of bleeding risk. The factors which determine the time duration of pause are the renal function of the patient and peri-operative bleeding possibility. In case the patient has administered with medications that increase the half-life of NOACs, the pre-operative pause should be prolonged up to $12 \mathrm{~h}[21,22]$. Bridging with heparin is not mandatory for NOACs. The drug therapy can be resumed only when the risk of peri-operative bleeding has become lowered and gastro-intestinal passage is back to normal. NOAC is re-established within $6-8 \mathrm{~h}$ and the farthest being $24 \mathrm{~h}$ post-operation for procedures having low bleeding risk [21-23]. For operations with a high risk of bleeding, NOACs are restarted within 48-72 h post-operatively [21].

If there occurs an emergency for surgery with high peri-operative bleeding risk, the administration of antidote is considered. The level of drug in plasma should be assessed before the administration of an antidote [24, $25]$. It is done to assess the level of coagulation. Idarucizumab is the recognized antidote to dabigatran. It is administered before emergency surgical procedures having a high possibility for bleeding and also the plasma level of the drug is above $30 \mathrm{ng} / \mathrm{ml}$. In major bleeding conditions, idarucizumab might be given at plasma level above $50 \mathrm{ng} / \mathrm{ml}$. Idarucizumab shows a high affinity for binding to dabigatran and its metabolites. It eliminates the complex renally. Idarucizumab is administered intravenously at 2.5 -mg dose initially and then a maintenance dose within $15 \mathrm{~min}$ [24-26]. For factor $\mathrm{Xa}$ inhibitors, andexanet alpha is the approved antidote in major bleeding events. Andexanet alpha acts by binding with the agents and eliminates it. In bleeding conditions, an IV bolus and a continuous intravenous infusion of the drug is administered for $120 \mathrm{~min}$. The low-dose regimen is $400 \mathrm{mg}$ bolus $+4 \mathrm{mg} / \mathrm{min}$ infusion, and the high-dose regimen is $800 \mathrm{mg}$ bolus $+8 \mathrm{mg} / \mathrm{min}$ infusion. What regimen to be chosen is determined by the dose of anticoagulant and time period after the last intake. Aripazine or PER 977 is the universal antidote for NOACs, on which clinical trials are going on [27] (Table 3).

\section{Advantages}

NOACs become popular in the market due to advantages over traditional anticoagulants. Some of the many advantages are dealt here. Firstly, it has erased the need for heparin bridging as it has sudden onset as well as offset action, which eliminates the chances of bleeding if the patient requires surgical treatments. Along with these benefits, the rapid onset and offset actions mean any patient with acute thrombosis does not require any initial treatment with a parenteral anticoagulant [29].

Its popularity accounts not only for its predictable anticoagulant effects which in turn reduce the need for a routine coagulation monitoring but also its convenience for the patients as NOACs have fixed daily oral doses. This is possible since they have predictable PK properties and absolute bioavailability, regardless of the demographic variables [30].

Most importantly, the actions of NOACs are not affected by the intake of foods. Hence, the patient does not need to avoid certain foods or put any dietary restrictions [31]. Also, due to the wide therapeutic window, the chances of bleeding complications are exponentially reduced. NOACs have specific coagulation enzyme targets; therefore, off-target adverse effects are almost nil. It also shows greater efficacy in patients 
Table 3 Pre- and post-operative care for patients on NOACs [28]

\begin{tabular}{|c|c|c|c|c|c|}
\hline \multirow[t]{2}{*}{ Drug } & \multicolumn{3}{|l|}{ Minor surgical procedure } & \multicolumn{2}{|l|}{ Major surgical procedure } \\
\hline & $\begin{array}{l}\text { Renal function(based on creatinine } \\
\text { clearance) }\end{array}$ & Pre-operative care & $\begin{array}{l}\text { Post- } \\
\text { operative } \\
\text { care }\end{array}$ & Pre-operative care & $\begin{array}{l}\text { Post- } \\
\text { operative } \\
\text { care }\end{array}$ \\
\hline \multirow[t]{2}{*}{ Dabigatran } & $\begin{array}{l}\text { Normal function or mild impairment } \\
\text { with creatinine clearance greater than } \\
50 \mathrm{ml} / \mathrm{min}\end{array}$ & $\begin{array}{l}\text { Withhold therapy for } 2 \text { days } \\
\text { prior to surgery (i.e. omit } 2 \\
\text { doses) }\end{array}$ & $\begin{array}{l}\text { Resume } 24 h \\
\text { following } \\
\text { surgery }\end{array}$ & $\begin{array}{l}\text { Withhold therapy for } 3 \text { days } \\
\text { prior to surgery (i.e. omit } 4 \\
\text { doses) }\end{array}$ & $\begin{array}{l}\text { Resume } 48 \mathrm{~h} \\
\text { following } \\
\text { surgery }\end{array}$ \\
\hline & $\begin{array}{l}\text { Moderate impairment with creatinine } \\
\text { clearance between } 30-50 \mathrm{ml} / \mathrm{min}\end{array}$ & $\begin{array}{l}\text { Withhold therapy for } 3 \text { days } \\
\text { prior to surgery (i.e. omit } 4 \\
\text { doses) }\end{array}$ & $\begin{array}{l}\text { Resume } 24 h \\
\text { following } \\
\text { surgery }\end{array}$ & $\begin{array}{l}\text { Withhold therapy for } 4-5 \text { days } \\
\text { prior to surgery (i.e. omit } 6-8 \\
\text { doses) }\end{array}$ & $\begin{array}{l}\text { Resume } 48 \mathrm{~h} \\
\text { following } \\
\text { surgery }\end{array}$ \\
\hline Rivaroxaban & $\begin{array}{l}\text { Normal, mild, or moderate impairment } \\
\text { with creatinine clearance greater than } \\
30 \mathrm{ml} / \mathrm{min}\end{array}$ & $\begin{array}{l}\text { Withhold therapy for } 2 \text { days } \\
\text { prior to surgery (i.e. omit } 1 \\
\text { dose) }\end{array}$ & $\begin{array}{l}\text { Resume } 24 h \\
\text { following } \\
\text { surgery }\end{array}$ & $\begin{array}{l}\text { Withhold } 3 \text { days prior to } \\
\text { surgery (i.e. omit } 2 \text { doses) }\end{array}$ & $\begin{array}{l}\text { Resume } 48 \mathrm{~h} \\
\text { following } \\
\text { surgery }\end{array}$ \\
\hline Edoxaban & $\begin{array}{l}\text { Normal, mild, or moderate impairment } \\
\text { with creatinine clearance greater than } \\
30 \mathrm{ml} / \mathrm{min}\end{array}$ & $\begin{array}{l}\text { Withhold therapy for } 2 \text { days } \\
\text { prior to surgery (i.e. omit } 1 \\
\text { dose) }\end{array}$ & $\begin{array}{l}\text { Resume } 24 h \\
\text { following } \\
\text { surgery }\end{array}$ & $\begin{array}{l}\text { Withhold } 3 \text { days prior to } \\
\text { surgery (i.e. omit } 4 \text { doses) }\end{array}$ & $\begin{array}{l}\text { Resume } 48 \mathrm{~h} \\
\text { following } \\
\text { surgery }\end{array}$ \\
\hline Apixaban & $\begin{array}{l}\text { Normal, mild, or moderate impairment } \\
\text { with creatinine clearance greater than } \\
30 \mathrm{ml} / \mathrm{min}\end{array}$ & $\begin{array}{l}\text { Withhold therapy for } 2 \text { days } \\
\text { prior to surgery (i.e. omit } 1 \\
\text { dose) }\end{array}$ & $\begin{array}{l}\text { Resume } 24 \mathrm{~h} \\
\text { following } \\
\text { surgery }\end{array}$ & $\begin{array}{l}\text { Withhold } 3 \text { days prior to } \\
\text { surgery (i.e. omit } 4 \text { doses) }\end{array}$ & $\begin{array}{l}\text { Resume } 48 \mathrm{~h} \\
\text { following } \\
\text { surgery }\end{array}$ \\
\hline
\end{tabular}

having atrial fibrillation. And they are less prone to have intracranial haemorrhage (ICH) with an exception for dabigatran $(150 \mathrm{mg}$ of the drug causes equal rate of $\mathrm{ICH}$ as warfarin) [32].

Lastly, the studies show that NOACs have minimal interactions with other drugs. It permits the concomitant administration of other drugs with NOACs. It is unlike VKAs which exhibit a wide range of drug interactions [9].

\section{Challenges}

Even though NOACs brought about several advantages over VKAs, there still exist some challenges that need to be overcome. Even though current guidelines favour the use of NOACs, there are several domains that need contemplation and studies to guarantee the safe and effective use of the drug. It lacks empirical evidence on its proper use which makes clinicians less interested to switch over to NOACs [2]. Some of the main demerits are addressed below.

The drug acquisition costs are higher for NOACs compared to VKAs; hence, it limits the usage. This makes the healthcare system prefer warfarin over NOACs though INR is poorly controlled with it [1].

Unlike warfarin, NOACs lack the need for routine investigation of the drug in plasma or modification of dose except for emergency situations where the drug exposure assessment is required. This arena demands a large number of studies, because most of the tests are not reliable and provide accurate tests. There is only limited evidence available to assess the coagulation testing ability [2]. Primarily, specific tests are still not routinely available in many centres. Even if available, the expertise is not available round the clock. Thus, it is difficult to assess the level of coagulation in emergency situations. Also, there are no international calibration standards for the assays. Thus, there are chances for considerable variations between laboratories [33].

There is no system to optimize non-compliance of NOACs like VKAs. This is due to the shorter half-life of the drugs. Thus patients require follow-up to ensure their medication compliance. The endurance with NOACs is unsatisfactory and efforts are in progress to enhance compliance $[1,2]$.

Switching from NOAC to warfarin is a bit complex. Warfarin shows gradual outset of action (5-10 days). Thus, NOACs should be administered along with warfarin till the INR is in the desired value. Once sole therapy is in place, the INR should be re-evaluated $24 \mathrm{~h}$ after the last dose of NOACs. This is done to guarantee adequate anticoagulation. Close monitoring of INR is suggested for the first month until stable INR values are achieved [34].

For CKD patients, a yearly examination of renal function is advised especially for dabigatran (80\% elimination renally). The current ESC guidelines state that the use of NOACs is undesirable in CKD patients having $\mathrm{CrCl}<30$ $\mathrm{ml} / \mathrm{min}$. Administration of NOACs is not suggested in patients with AF and undergoing haemodialysis [35, 36].

The dose adjustments are done according to the patient characteristics outlined in the monograph of each agent since there is very little evidence in suggestion to improve safety levels of the drug in relation to clinical characteristics like age, renal function, and concomitant medications [1].

Dose adjustment for patients at extremes of body weight is still debated upon as data on these clinical trials are insufficient at present [1].

There are limited studies with regard to the usage of NOACs in pregnant women and breast feeding mothers along with patients having hepatic disease. 
Whether it is safe on long-term use or not has not yet been confirmed [7].

\section{Future trends of NOACs (conclusion)}

The forthcoming years tend to show a tremendous increase in the use of NOACs. This can be understood from the rate of usage of NOACs in recent years. This is the result of better patient compliance, safety profile, and easier management of these drugs compared to traditional anticoagulants. Globally, the medical practitioners eagerly use NOACs over VKAs but are uncertain to use due to the limited evidence [2]. However, it will have greater progress in the near future as many studies are being conducted that will make it more accessible to the patients in terms of dosing regimen and efficacy. The cost will gradually reduce to an affordable price [2]. Innovative protocols will be designed to minimize the possibility of haemorrhage [37]. Advanced studies will be carried out to determine dosing patterns for special populations such as pregnant and lactating women, geriatrics and paediatrics, and patients with renal and hepatic dysfunction [7]. Many studies are being conducted to authorize the safety in long-term use of drugs [7]. International standards for specific assays for NOACs are to be established to alleviate the variation in the results of laboratory values [11].

\section{Abbreviations}

NOACs: Novel oral anticoagulants; VKA: Vitamin K antagonist; $\mathrm{CrCl}$ : Creatinine clearance

\section{Acknowledgements \\ I would like to acknowledge Mr. Shafi M.H., who aided by giving technical support as well as provided us important suggestions regarding the collection of data for the article. \\ Dr. Merin Sunny has showed profound interest in helping write the article. Also, she has pointed technical corrections for the article. \\ Ms. Sonu Benny has given valuable suggestions on preparing the article. Mr. Paily V. and Mrs. Anie Paul are two important personalities who stood with us from the starting to the completion of article. Their brilliant ideas and positive suggestions on data analysis and manuscript writing have helped to improve the quality of the article to a greater extent.}

\section{Consent for acknowledgement}

We have received the permission to acknowledge from all the persons mentioned in the "Acknowledgements" section

\section{Authors' contributions \\ Ms. CP has played a critical role in collection and analysation of data regarding the topic. Her immense contribution to writing the manuscript is irreplaceable. She is the main author and has shown immense interests for the work. She has approved the submitted version. Ms. MB was a contributor in data collection and aided in writing the manuscript. Dr. AR has made critical suggestions to the conception and substantively revised the work. Dr. KK was the supporting pillar for writing manuscript and drafted the work. All authors have read and approved the manuscript.}

\section{Funding}

No funding

\section{Availability of data and materials}

Data sharing not applicable to this article as no data sets were generated or analysed during the current study.
Ethics approval and consent to participate

Not applicable

Consent for publication

Not applicable

\section{Competing interests}

Authors declare that they have no competing interest.

\section{Author details}

'Department of Pharmacy Practice, St. James' College of Pharmaceutical Sciences, St. James' Hospital Trust Pharmaceutical Research Centre (DSIR recognized), Chalakudy, Kerala, India. ${ }^{2}$ Department of Pharmaceutical Chemistry, St. James' College of Pharmaceutical Sciences, St. James' Hospital Trust Pharmaceutical Research Centre (DSIR recognized), Chalakudy, Kerala, India.

Received: 28 May 2020 Accepted: 15 September 2020

Published online: 24 November 2020

\section{References}

1. Yeh CH, Hogg K, Weitz JI (2015) Overview of the new oral anticoagulants opportunities and challenges. Arterioscler Thromb Vasc Biol. 35:1-9

2. Dalal JJ, Dhall A, Bhave A (2016) Current perspective on use of NOAC in clinical practice in India. J Assoc Physic India 64:56-62

3. Riva N, Ageno W (2015) Pros and cons of vitamin K antagonists and non-vitamin K antagonist oral anticoagulants. Semin Thromb Hemost. 41:178-187

4. Sarich TC, Seltzer JH, Berkowitz SD, Costin J, Curnutte JT, Gibson CM, Hoffman M, Kaminskas E, Krucoff MW, Levy JH, Mintz PD, Reilly PA, Sager PT, Singer DE, Stockbridge N, Weitz Jl, Kowey PR (2015) Novel oral anticoagulants and reversal agents: Considerations for clinical development. Am Heart J.0:1-7

5. Olson H (2016) Advantages and disadvantages of novel oral anticoagulants. http://www.dicardiology.com. Accessed on 26 Apr 2020

6. Muck W, Schwers S, Stampfuss J (2013) Rivaroxaban and other novel oral anticoagulants: pharmacokinetics in healthy subjects, specific patient populations and relevance of coagulation monitoring. Thrombosis J 10:10-13

7. Lexicomp (2020) http://www.online.lexi.com. Accessed 15 Apr 2020

8. Chan N, Sager PT, Lawrence J, Ortel T (2018) Is there a role for pharmacokinetic/pharmacodynamic-guided dosing for novel oral anticoagulants? Am Heart J 199:59-67

9. Mekaj YH, Mekaj AY, Duci SB, Miftari El (2015) New oral anticoagulants: their advantages and disadvantages compared with vitamin $\mathrm{K}$ antagonists in the prevention and treatment of patients with thromboembolic events. Ther Clin Risk Manag 11:967-977

10. Saljoughian M (2018) Assessing novel oral anticoagulants. US Pharm 43(2): 13-14

11. Salmonson T, Dogne JM, Janssen H, Burgos JG, Blake P (2016) Non-vitamin $K$ oral anticoagulants and laboratory testing: now and in the future. Eur Heart J Cardiovasc Pharmacother. 3(1):42-47

12. Lindhoff-Last E, Samama MM, Ortel TL, Weitz JI, Spiro TE (2010) Assays for measuring rivaroxaban: their suitability and limitations. Ther Drug Monit. 32: 673-679

13. Siegal DM, Crowther MA (2013) Acute management of bleeding in patients on novel oral anticoagulants. Eur Heart J 34:489-498

14. Samama MM, Martinoli JL, Le Flem L, Guinet C, Plu-Bureau G, Depasse F, Perzborn E (2010) Assessment of laboratory assays to measure rivaroxaban an oral, direct factor Xa inhibitor. Thromb Haemost 103:815-825

15. Samama MM, Contant G, Spiro TE, Perzborn E, Flem LL, Guinet C, Gourmelin $Y$, Martinoli $J$ (2012) Evaluation of the prothrombin time for measuring rivaroxaban plasma concentrations using calibrators and controls: results of a multicenter field trial. Clin Appl Thromb Hemost 18:150-158

16. Douxfils J, Mullier F, Robert S, Chatelain C, Chatelain B, Dogne JM (2012) Impact of dabigatran on a large panel of routine or specific coagulation assays. Laboratory recommendations for monitoring of dabigatran etexilate. Thromb Haemost 107:985-997

17. Samama MM, Guinet C (2011) Laboratory assessment of new anticoagulants. Clin Chem Lab Med 49:761-772 
18. Wagner J, Lock JF, Kastner C, Klein I, Krajinovic K, Lob S, Germer CT, Wiegering A (2019) Perioperative management of anticoagulant therapy. Innov Surg Sci 4(4):144-151

19. Samama MM, Contant G, Spiro TE, Perzborn E, Guinet C, Gourmelin Y, Le Flem L, Rohde G, Martinoli JL (2012) Evaluation of the anti-Factor Xa chromogenic assay for the measurement of rivaroxaban plasma concentrations using calibrators and controls. Thromb Haemost 107: 379-387

20. Slavik L, Lukes J, Friedecky D, Zhanelova M, Nemcova M, Ulehlova J, Prochazkova J, Hlusi A, Palova M, Vaclavik J (2018) Multianalyte determination of NOACs using LC-MS/MS64:1611-1621

21. Steffel J, Verhamme P, Potpara TS, Albaladejo P, Antz M, Desteghe L, Haeusler KG, Oldgren J, Reinecke H, Roldan-Schilling V, Rowell N, Sinnaeve P, Collins R, Camm JA, Heidbuchel H (2018) The 2018 European Heart Rhythm Association practical guide on the use of nonvitamin $\mathrm{K}$ antagonist oral anticoagulants in patients with atrial fibrillation. Eur Heart J 39:1330-1393

22. Faraoni D, Levy JH, Albaladejo P, Samama C-M (2015) Updates in the perioperative and emergency management of non-vitamin $\mathrm{K}$ antagonist oral anticoagulants. Crit Care (London, England) 19:203

23. Spyropoulos AC, Al-Badri A, Sherwood MW, Douketis JD (2016) Periprocedural management of patients receiving a vitamin $\mathrm{K}$ antagonist or a direct oral anticoagulant requiring an elective procedure or surgery. J Thromb Haemost 14:875-885

24. Levy JH, Ageno W, Chan NC, Crowther M, Verhamme P, Weitz Jl (2016) When and how to use antidotes for the reversal of direct oral anticoagulants Guidance from the SSC of the ISTH. J Thromb Haemost. 14: 623-627

25. Farina N, Miller JT (2018) Pharmacologic reversal of direct oral anticoagulants. Crit. Care Nurs. Q 41:121-128

26. Pollack CV, Reilly PA, Weitz JI (2017) Dabigatran reversal with idarucizumab. N Engl J Med 377:1691-1692

27. TJ M Jr, Kaatz S (2016) Preclinical and clinical data for factor Xa and universal reversal agents. Am J Med. 129:80-88

28. Dr. Sharma V (2016) Novel Oral Antcoagulant Drugs- Have they replaced VKAs? Paper presented at Department of Cardiology, National Heart Institute, New Delhi, 2016

29. Bauer K A (2013) Pros and cons of new oral anticoagulants. Hematol Am Soc Hematol Educ Program :464-470

30. Kubitza D, Becka M, Voith B, Zuehlsdorf M, Wensing G (2005) Safety, pharmacodynamics, and pharmacokinetics of single doses of BAY-59-7939, an oral, direct factor Xa inhibitor. Clin Pharmacol Ther. 78(4):412-421

31. Hoffman R, Brenner B (2012) The promise of novel direct oral anticoagulants. Best Pract Res Clin Haematol. 25(3):351-360

32. Connolly SJ, Ezekowitz MD, Yusuf S, Eikelboom J, Oldgren J, Parekh A, Pogue J, Reilly PA, Themeles E, Varrone J, Wang S, Alings M, Xavier D, Zhu J, Diaz R, Lewis BS, Darius H, Diener HS, Joyner CD, Wallentin L (2009) Dabigatran versus warfarin in patients with atrial fibrillation. N Engl J Med. 361(12):1139-1151

33. Favaloro JE, Pasalic L, Curnow J, Lippi G (2017) Laboratory monitoring or measurement of direct oral anticoagulants (DOACs): advantages, limitations and future challenges. Bentham Sci Publishers 18(7):598-608

34. Schulman S, Crowther MA (2012) How I treat with anticoagulants in 2012: new and old anticoagulants, and when and how to switch. Blood 119(13): 3016-3023

35. Heidbuchel H, Verhamme P, Alings M, Antz M, Diener HS, Hacke W, Oldgren J, Sinnaeve P, Camm JA, Kirchhof P (2013) EHRA practical guide on the use of new oral anticoagulants in patients with nonvalvular atrial fibrillation: executive summary. Eur Heart J 34:2094-2106

36. Bauer KA (2013) Pros and cons of new oral anticoagulants. Hematology Am Soc Hematol Educ Program:464-470

37. Sarah L, Sophie DA, Jonathan $D$, Bérangère $D$, Jean-Baptiste $N$, Anne $S$, Anne-Sophie L, Jean-Michel D, Maximilien G, François M (2014) Preventive strategies against bleeding due to nonvitamin $\mathrm{K}$ antagonist oral anticoagulants. Biomed Res Int 2014:616405

\section{Publisher's Note}

Springer Nature remains neutral with regard to jurisdictional claims in published maps and institutional affiliations.

\section{Submit your manuscript to a SpringerOpen ${ }^{\circ}$ journal and benefit from:}

- Convenient online submission

- Rigorous peer review

- Open access: articles freely available online

- High visibility within the field

- Retaining the copyright to your article

Submit your next manuscript at $\boldsymbol{\nabla}$ springeropen.com 